Nr 1(70), 2021, s. 179-196

https://doi.org/10.12797/Politeja.18.2021.70.14

\author{
Barbara WEŻGOWIEC (D) \\ Uniwersytet Jagielloński w Krakowie \\ b.wezgowiec@uj.edu.pl
}

\title{
OD ZNIKANIA DO ODPOMINANIA
}

\author{
POSTPAMIĘCIOWE NARRACJE O MIEDZIANCE
}

ABSTRACT From Disappearance to Re-Remembrance. Post-Memory Narration about Miedzianka

Miedzianka - a lower Silesian village, earlier: mining town and a leisure-tourist resort, ger. Kupferberg. It is said that it is a ghost-town, which has (almost) disappeared. Some traces, however, remained - a church, photography or human memories - both from before World War II, of German citizens and after the world war of Polish inhabitants. All of them are connected by the traumatic experience that combines post-war resettlement and the destruction of the town. The memory of Miedzianka was not destroyed, though, being passed to next generations. One of the voices of this post-memory can be found in the report by Filip Springer, Miedzianka: Story of Disappearing in 2011. This book quickly became recognised ensuing an increasing interest in the town, its history and fate, making new post-memory narrations to appear, which I describe as "post-memory practice". One of them is Miasto, którego nie byto (A City, Which Didn't Exist). What and how do these books tell us about Miedzianka? In what sense do these alternative but interpenetrating narrations influence the perception of this place, as well as the memory of it? These questions are the basis of the reflections leading to a display of relations between man and his oblivion/memory and the place. The literature, however, or widely art, having the power to preserve memory and therefore to save, allows the showcasing of the transformation of the town: its history, disappearance, and finally transubstantiation into a place of memory, which is created mainly by the second and third generations - heritage depositories.

Keywords: post-memory, Miedzianka, Filip Springer, art, place of memory

Słowa kluczowe: postpamięć, Miedzianka, Filip Springer, sztuka, miejsce pamięci 


\section{TYTUŁEM WSTĘPU: ŚLADY}

W Stowniku geografii turystycznej Sudetów pod hasłem „Miedzianka” widnieje taka oto informacja: [...] potożona na wysokości 470-530 m n.p.m. Dziś jest to zaledwie kilka domów otoczonych licznymi hatdami i wyrobiskami, pozostatościa po pracach górniczych o 700-letniej historii, oraz ruinami jednego zpiękniejszych ślaskich miast. Miasto nazywane przed $1945 \mathrm{r}$. Kupferberg ${ }^{1}$. Mówi się o niej, że to miasto widmo, które niemalże zniknęło. Pozostały jednak ślady - w postaci kościoła, fotografii, dawnych pocztówek czy ludzkich wspomnień - zarówno tych przedwojennych, niemieckich mieszkańców, jak i powojennych - polskich. Na tych śladach oparł się Filip Springer w swoim reportażu z 2011 r. pt. Miedzianka. Historia Znikania. Książka szybko zyskała rozgłos i przyczyniła się do ponownego zainteresowania miasteczkiem, jego historią i losami, rozpoczynając tym samym - by posłużyć się terminem Huberta Orłowskiego - „odpominanie” Miedzianki. Uruchomiona została postpamięć, a właściwie rozmaite praktyki postpamięci, do których zaliczyć można kolejne wystawy, spektakle teatralne, szlak, komiks, a nawet mural poświęcony Miedziance.

Jedną z nich jest publikacja pt. Miasto, którego nie byto/ Die Stadt, die nicht gewesen ist, pod redakcją Janiny Hobgarskiej, Aurelii Nowak i Marka Wasilewskiego, której powstanie bezpośrednio związane jest z reportażem Springera (ale i Miedzianką jako taką). Znajdują się w niej eseje, dla których wspólnym mianownikiem jest poszukiwanie tożsamości miejsca oraz fotografie, opisy, a także komentarze do realizacji artystycznych doktorantów Uniwersytetu Artystycznego w Poznaniu i jeleniogórskich fotografów, które znalazły się na poprzedzającej publikację wystawie w BWA w Jeleniej Górze w 2013 r. Obydwie publikacje (i narracje) lączy fakt, że ich autorami są osoby niezwiązane z Miedzianką ani jej mieszkańcami, niemające tutaj swoich korzeni. Trudno zatem wskazać na bezpośrednie dziedziczenie pamięci, jednakże zarówno Springer, jak i uczestnicy projektu artystycznego, poruszeni historią tego miejsca, poczuli się niejako depozytariuszami pamięci o Miedziance. W ich postpamięciowych narracjach, wynikających po części z empatii, po wtóre z próby zrozumienia, dlaczego i jak możliwe stało się zniknięcie miasta, a także z chęci upamiętnienia jego losów i mieszkańców, uwidaczniają się wskazywane przez prekursorkę badań nad postpamięcią Marianne Hirsch „kreacja i wyobraźnia”. Jak te elementy funkcjonują i na ile „fundują" obydwa dzieła, a dalej: dlaczego, co i jak wymienione narracje mówią o Miedziance? W jaki sposób wpływają na kształtowanie i odbieranie samego miejsca oraz budowanie pamięci o nim? Te pytania stanowią podstawę refleksji, służącej ukazaniu możliwych sposobów

Stownik geografii turystycznej Sudetów, t. 5 Rudawy Janowickie, red. M. Staffa, Wrocław 1998, s. 194.

2 „Odpominanie” za Hubertem Orłowskim pojmuję jako świadomą pracę pamięci, która wiąże się nie tylko z przypominaniem - odzyskaniem zapomnianych treści - ale przede wszystkim z uświadomieniem sobie ich istnienia. Zob. H. Orłowski, Warmia z oddali. Odpominania, Olsztyn 2000.

3 Zob. M. Hirsch, Past Lives: Postmemories in Exile, „Poetics Today” 1996, vol. 17, nr 4, s. 664, cyt. za: A. Szczepan, Polski dyskurs posttraumatyczny. Literatura polska ostatnich lat wobec Holocaustu i tożsamości żydowskiej, [w:] Kultura po przejściach, osoby z przesztością. Polski dyskurs postzależnościowy konteksty i perspektywy badawcze, red. R. Nycz. Kraków 2011, s. 241. 
odpominania historii (nie tylko ${ }^{4}$ ) Miedzianki. Omówienie tych tekstów na tle porównawczym stanowi - w szerszym kontekście - głos w dyskusji na temat relacji między człowiekiem, jego (nie)pamięcią ${ }^{5}$ i miejscem.

Wspomnę przy tym, że termin postpamięć (autorstwa Hirsch) rozumiem szeroko jako kategorię odnoszącą się do pamięci o traumatycznych przeżyciach właściwą nie pokoleniu, które jej doświadczyło, ale dzieciom i wnukom. Na takie szerokie ujęcie zgadzała się zresztą sama autorka terminu, wskazując, że może on postużyć do mówienia opamięci drugiego pokolenia, która dotyczy innych kulturowych, czy zbiorowych wydarzeń $i$ doświadczeń traumatycznych ${ }^{6}$. Owa postpamięć opiera się na empatycznym odtwarzaniu doświadczenia tej generacji ${ }^{7}$. Hirsch wskazuje, że ta forma pamięci łączy się ze swoim źródłem nie przez przypominanie, lecz przez wkład wspomnianej już „kreacji i wyobraźni”. Dodać można, że realizuje się ona także w działaniach (np. geście pisarskim, artystycznym, poszukiwaniu informacji) podejmowanych - w tym przypadku - w danej przestrzeni i wobec owego miejsca, w których to czynnościach, praktykach dokonuje się owo empatyczne „połączenie” z minionymi generacjami i ich doświadczeniem.

W interesujących mnie publikacjach mówiących o miejscu z polsko-niemieckiego pogranicza doświadczenie traumy wiąże się $\mathrm{z}$ dwoma wydarzeniami: przesiedleniami (a zatem i wykorzenieniem, wskazywanym z kolei przez Romanę Kolarzową jako doświadczenie, które wywołuje emocje przekazywane kolejnym pokoleniom ${ }^{8}$ ) będącymi konsekwencją II wojny światowej oraz niszczeniem i zapadaniem się miasta, z którego do dzisiaj pozostał jedynie kościól, kilka budynków, znajdujący się nieopodal pokutny krzyż i uwidaczniające się w nierównościach terenu fragmenty zabudowań. A przecież było tu miasteczko - niewielkie, ale mające swój browar, kościoły (ewangelicki i katolicki), rynek i kamienice oraz domy mieszkańców, których nie „naruszyły” wojny. Springer pytał zatem, dlaczego Miedzianka zniknęła z powierzchni ziemi i zaniknęła na kilka dekad w ludzkiej pamięci, warto dopytać: co legło u podstaw ponownego zainteresowania się tym miejscem i do czego przyczyniło się przypomnienie historii „znikania” miasta oraz jak ta historia jest odpominana?

W szerszym ujęciu można postpamięciowe praktyki związane z Miedzianką zestawić z innymi tego typu działaniami wokół tzw. miast o „wymienionej krwi” (termin Marii Lewickiej, zob. tejże, Psychologia miejsca, Warszawa 2012, s. 451-461) czy np. narracjami Stasiuka dotyczącymi Beskidu Niskiego.

5 Niepamięć pojmuję tutaj w sposób bliski pojmowania Paula Ricoeura, który określił ją jako lukę w pamięci zbiorowej danej społeczności mogącą powstawać zarówno w wyniku zaniedbania, jak i zaplanowanego wymazywania ze zbiorowej świadomości pamięci o jakichś wydarzeniach. Zob. P. Ricoeur, Pamięć, historia, zapomnienie, przeł. J. Margański, Kraków 2012, s. 553.

6 Zob. M. Hirsch, Żatoba i postpamię́, przeł. K. Bojarska, [w:] Teoria wiedzy o przesztości na tle wspótczesnej humanistyki. Antologia, red. E. Domańska, Poznań 2010, s. 255; por. tejże, Family Frames. Photography, Narrative and Postmemory, Cambridge 1997, s. 22.

7 K. Kaniowska, "Memoria” i „postpamięc ” a antropologiczne badanie wspólnoty, [w:] Codzienne i niecodzienne. O wspólnotowości w realiach dzisiejszej Łodzi, red. G.E. Karpińska, Łódź 2004, s. 20. Inaczej tę kategorię określa się jako nie-pamięć, pamięć nieobecną, odziedziczoną, „podziurawioną” czy też zastępcze bycie świadkiem.

$8 \quad$ R. Kolarzowa, Zwidy, majaki, powidoki czyli meandry postpamięci. Między Dominkiem LaCapra a Giorgio Agambenem, „Kwartalnik Filozoficzny” 2015, vol. 43, z. 3, s. 123. 


\section{POSTPAMIĘCIOWA BIOGRAFIA MIEJSCA - O MIEDZIANCE Z REPORTAŻU FILIPA SPRINGERA ${ }^{9}$}

Miedzianka w Miedziance. Historii znikania jest miasteczkiem, a właściwie miejscem najbliższym miejscu dotkniętemu według typologii miejsc autobiograficznych Małgorzaty Czermińskiej ${ }^{10}$, „przystankiem” w podróży po Dolnym Śląsku, który stał się swego rodzaju miejscem wybranym ${ }^{11}$. Filip Springer w jednym z wywiadów wspomniał, że o Miedziance zasłyszał podczas wędrówki po okolicznych Rudawach Janowickich ${ }^{12}$. Bezpośrednim impulsem do zajęcia się jej historią stała się dawna fotografia miastecz$\mathrm{ka}^{13}$ zestawiona $\mathrm{z}$ łąką, która po nim została, oraz (bardziej anegdotycznie) znaleziony kapsel od butelki po piwie wytwarzanym właśnie tutaj i określanym mianem „złota Kupferbergu/Miedzianki”. Ów nakaz pamiętania - jak wskazuje Springer - wypisany jest także na jednej z niewielu materialnych pozostałości po Miedziance, pokutnym krzyżu z napisem „Memento”. Autor niejednokrotnie przywołuje go w swoim reportażu, wskazując na wszechobecność i nachalność owego nakazu. Memento nie pozwalato o sobie zapomnieć, wystawato zza traw za kazdym razem, gdy ktośspojrzat w tamta strone $e^{14}$. Widok spokojnego urokliwego miasteczka w zderzeniu z pustką po nim i wyrytym na umiejscowionym nieopodal kamiennym krzyżu napisem „Memento” stał się wstrząsem na tyle mocnym, że pisarz postanowił dociec, jak doszło do zagłady miasteczka, którego nie zniszczyły wojny, a kres nastąpił prawie 30 lat później. Niedająca mu spokoju informacja kazała także dotrzeć do bezpośrednich świadków owego zniszczenia. Przez kolejne dwa lata Springer poszukiwał zatem śladów, przeglądał archiwalia, docierał do dawnych mieszkańców, świadków, by znaleźć odpowiedzi na nurtujące go pytania. Jednocześnie z turysty, który przypadkowo usłyszał pewną historię, zaczął zmieniać się w badacza, reportażystę, słuchacza, a wreszcie depozytariusza (post)pamięci o tym miejscu. W kontekście problematyki postpamięci warto zaznaczyć, że wcielając się w reportażystę, który nie brał bezpośredniego udziału w opisywanych wydarzeniach, Springer starał się połączyć w swojej opowieści pamięć zarówno bezpośrednich

9 Szczegółowe omówienie Miedzianki pod względem gatunkowym znaleźć można m.in. w: B. Darska, Pamięć codzienności, codzienność pamiętania. Szkice o reportażu polskim XXI wieku, Gdańsk 2014, s. 78-92; E. Żyrek-Horodyska, Kartografowie codzienności. O przestrzeni (w) reportażu, Kraków 2019, s. 141-146.

10 Zob. M. Czermińska, Miejsca autobiograficzne. Propozycja w ramach geopoetyki, „Teksty Drugie” 2005, nr 5, s. 198-199.

11 Trzeba nadmienić, że Springer już po wydaniu Miedzianki wracał do niej niejednokrotnie, m.in. od 2017 r. zorganizował tam festiwal literacki „Miedzianka Fest”, a w 2019 r. uhonorowano go I Karkonoską Nagrodą Literacką, nagroda specjalna trafiła wówczas do rąk Lizy Palmes - tłumaczki reportażu na język niemiecki, zob. Karkonoska Nagroda Literacka 2019 wręczona!, [online] http://www.kpswjg. $\mathrm{pl} / \mathrm{pl} /$ news/karkonoska-nagroda-literacka-2019-wreczona, 30 VIII 2020.

12 Zob. K. Kazimierowska, Rozmowa z Filipem Springerem o ksiażce Miedzianka, „Rzeczpospolita” 2011, 10 XI, [online] https://www.rp.pl/artykul/750083-Rozmowa-z-Filipem-Springerem-o-ksiazceMiedzianka.html, 23 VIII 2020.

13 Jak pisała Susan Sontag, Fotografie potrafia zapaść w pamięć mocniej [...], ponieważ rejestruja oddzielne jednostki czasu, a nie jego przeptyw", S. Sontag, O fotografii, przeł. S. Magala, Kraków 2009, s. 23.

14 F. Springer, Miedzianka. Historia znikania, Wołowiec 2011, s. 5. 
świadków (niemieckich i polskich mieszkańców najpierw Kupferbergu, a później Miedzianki), jak i kolejnych generacji, bo choć nierzadko pamięć i postpamięć tworzą odrębne narracje, tutaj nabierają charakteru komplementarnego. Pisarz korzysta przy tym często z mowy pozornie zależnej, przez co jego opowieść staje się polifoniczna ${ }^{15}$. Jednocześnie autor nie tyle odtwarza w niej same wydarzenia, ile przedstawia czytelnikowi pracę ludzkiej pamięci, stąd obok wspomnień (przede wszystkim) potomków dawnych mieszkańców, pojawiają się opowieści „legendarne” - o magicznych wręcz przyczynach zniknięcia miasteczka - jak i fotografie ze zbiorów prywatnych czy dawne pocztówki, czyli teksty kultury, przez które przekazywana pamięć o losach Kupferbergu/Miedzianki i jej mieszkańców jest przefiltrowana. Rolę fotografii w postpamięci podkreślała także sama Hirsch, wskazując, że jest ona dowodem na to, że ta-rzecz-tam-byta ${ }^{16}$ w przeszłości. Jednocześnie zdjęcia jako rezerwuar „zjaw” z przeszłości poniekąd przeszłość tę przywracają na zasadzie zastygłego w czasie pozoru trwałości, przestrzeń natomiast udostępnia realną płaszczyznę, na której owe widma się ujawniają, pokazuje ślady. Po dwóch latach stąpania po śladach, zbierania informacji o miejscu, „którego nie ma" i w którym spędził zasadniczą część owego czasu, z rozmów z dawnymi mieszkańcami oraz w oparciu o dostępne materiały pisarz zbudował opowieść, która - jak zauważyła Kamila Gieba - po części jest archiwum (tworzą je fotografie oraz historia, szczególnie niemieckich wieków Kupferbergu), po części zaś świadectwem jego istnienia (rozmowy z polskimi i niemieckimi mieszkańcami) ${ }^{17}$. Ten czynny udział Springera wyrażający się w poszukiwaniu pozostałości i próbie przywrócenia zagubionej pamięci miejsca jest jednym ze sposobów na odtworzenie utraconej więzi z przestrzenią (której już w dawnym wymiarze nie ma) i reprezentującymi ją generacjami.

Ogólnie można powiedzieć, że w przypadku Miedzianki literatura przejęła funkcję depozytariusza pamięci, który, jak wskazuje Gieba, nie tylko tę pamięć podtrzymuje i przechowuje, ale również ja w pewien sposób konstruuje ${ }^{18}$. I choć, jak zauważa Beata Kęczkowska, wielogtosowa opowieść o Miedziance nie daje odpowiedzi na wszystkie pytania, [...] pamięć o zanikniętym miasteczku na zawsze zostata utrwalona ${ }^{19}$. W tym zapisywaniu pamięci, czy też odpominaniu, pomocną stała się obrana przez autora strategia pisarska, określona przez Katarzynę Taborską mianem strategii kronikarskiej narratora

15 Jak zaznacza Edyta Żyrek-Horodyska, reportaż polifoniczny jest szczególnie uzasadniony w przypadku tematów związanych z pracą pamięci, forma ta bowiem pozwala ograniczyć subiektywizm autorskich ocen na rzecz prezentacji rozbudowanych wspomnień bohaterów. Reportażowy dyskurs o postpamięci. Casus więzów krwi Jeana Hatzfelda, „Kultura-Media-Teologia” 2018, nr 32, s. 46.

16 A. Sierbińska, Konstrukcje pamięci: „postpamięć” Marianne Hirsch, postpamięć Christiana Boltanskiego, „Konteksty. Polska Sztuka Ludowa” 2010, nr 1, s. 42.

17 Zob. K. Gieba, Memento dla prowincji. O Miedziance. Historii zanikania Filipa Springera, [w:] Pogranicza, Kresy, Wschód a Idee Europy. Seria II: Wiktor Choriew in memoriam, red. A. Janicka, G. Kowalski, Ł. Zabielski, Białystok 2013, s. 562.

18 Tamże, s. 561.

19 B. Kęczkowska, „Gazeta Wyborcza” 2011, 18 XI, cyt. za: L. Szura, Filip Springer, „Miedzianka. Historia znikania”, [online] https://culture.pl/pl/dzielo/filip-springer-miedzianka-historia-znikania, 30 VIII 2020. 
chcacego odtworzyć określony punkt widzenia świata ${ }^{20}$. Badaczka wskazuje także na traumę, która stała się podstawą dla uruchomienia praktyk postpamięci, gdyż jak pisze, gdyby uznać tytut za miejsce wyznaczajace hegemona narracji, to Miedzianka. Historia znikania staje się narracja z polska dominanta kompozycyjna. Opowieść jest bowiem podporządkowana polskiej tragedii miejsca ${ }^{21}$. Taborska podkreśla przy tym dwucentryczność narracji Filipa Springera. Pierwsza, niemiecka, dominuje w początkowej części reportażu przypominającej historię miasta do roku 1945, a że był to wówczas Kupferberg wszystkie nazwiska i inna nomenklatura występują w tym języku, nie towarzyszą im dodatkowe tłumaczenia czy wyjaśnienia ${ }^{22}$. Opisane są przemiany z miasteczka górniczego i browarniczego w jedno z najmniejszych uzdrowisk w Niemczech ${ }^{23}$, które właściwie nie ucierpiało podczas I i II wojny światowej. Później, po przemianie z Kupferbergu w Miedzianą Górę i (bardzo szybko) w Miedziankę, w reportażu dominuje już słownictwo polskojęzyczne; Springer przywołuje m.in. spolszczone nazwiska mieszkańców, którzy po wojnie dłużej zostali w Miedziance ${ }^{24}$. Zdaniem Taborskiej, Springer ze swoim reportażem wpisuje się $w$ nurt literatury pomnikowej ksztattującej tożsamość miejsca niemiecko-polskiego 25 .

Warto przy tym zaznaczyć, że wskazana przez badaczkę polska tragedia miejsca związana z jego zniknięciem - jak pokazuje Springer - był procesem rozciągniętym w czasie i złożyło się na niego kilka czynników. Jednym z nich było rabunkowe wydobycie uranu ${ }^{26}$, które w konsekwencji doprowadziło do powstania coraz większej liczby zapadlisk, pękania budynków itp. ${ }^{27}$. Istotną rolę odegrali tu także ludzie ${ }^{28}$. Z jednej strony

20 K. Taborska, Literatura miejsc niemiecko-polskich po roku 1989. Polonocentryczne strategie geografii wyobrażonej, [w:] Geografia wyobrażona regionu. Literackie figury przestrzeni, red. D. Kalinowski, M. Mikołajczak, A. Kuik-Kalinowska, Kraków 2014, s. 128. Dokładniejszy opis tej strategii znajduje się na s. 134-136.

${ }^{21}$ Tamże, s. 135. Zdaniem badaczki potwierdzeniem tej tezy jest także zakończenie opowieści, w której pojawiają się niemieckie akcenty ukazane z polskiejperspektywy.

22 Inne wersje nazw nie funkcjonowały, stąd występują tylko te „oryginalne”.

23 Szczegółowo historię miasta przytaczają Marcin Makuch i Tomasz Stolarczyk w publikacji wydanej z okazji 700. rocznicy pierwszej wzmianki o Miedziance, pt. Miedzianka. 700 lat górniczego miasta, Legnica 2013.

24 Zob. opowieść o Gliszczyńskich (von Glyschinsky), którzy jako ostatni Niemcy opuścili Miedziankę w 1957 r. F. Springer, Miedzianka..., s. 154-156.

K. Taborska, Literatura miejsc niemiecko-polskich..., s. 136.

26 Por. J. Klementowski, $W$ cieniu sudeckiego uranu. Kopalnictwo uranu $w$ Polsce $w$ latach 1948-1973, Warszawa 2010, s. 125, cyt. za: M. Makuch, T. Stolarczyk, Miedzianka. 700 lat..., s. 85; zob. też R. Witczak, Smutna historia dolnośląskiego miasteczka, [w:] Miasto, którego nie byto/ Die Stadt, die nicht gewesen ist, red. J. Hobgarska, A. Nowak, M. Wasilewski, przeł. K. Mądry, Z. Nierodziński, W. Wojciechowski, Jelenia Góra 2013, s. 30.

Warto wspomnieć, że zapadliska pojawiały się także wcześniej, stąd jeszcze przed wojną - w niemieckim Kupferbergu - podjęto decyzję o zamknięciu kopalń i przekształceniu Kupferbergu w uzdrowisko.

Wśród najbardziej zniszczonych i rozszabrowanych znalazł się dwór oraz kościół ewangelicki, który z uwagi na groźbę zawalenia - ostatecznie wyburzono. Por. R. Witczak, Smutna historia dolnoślaskiego miasteczka..., s. 31 i nast. 
mieszkańcom - częściowo niepewnym przyszłości tego miejsca - długo nie zależało na remontowaniu. Domy niszczały, opuszczone budynki niejednokrotnie służyły jako skład materiałów budowlanych dla nowych osiedleńców - nie tylko z miasteczka, ale i bliższej oraz dalszej okolicy - lub jako miejsce zabaw dla dzieci ${ }^{29}$. W 1972 r., po przesiedleniu większości mieszkańców do nowo budowanej dzielnicy Zabobrze w Jeleniej Górze $^{30}$, Prezydium Wojewódzkiej Rady Narodowej we Wrocławiu podjęło decyzję ${ }^{31}$ o likwidacji miasteczka, uznając ratowanie pozostałych obiektów za nieopłacalne, czy wręcz niemożliwe ${ }^{32}$. Romuald Witczak dodaje, że kiedy się patrzy na miejsce po Miedziance, doktadnie widać, że natura odzyskuje wszystko, co cywilizacja zabrata. Potrzebuje tylko czasu...33.

Można zatem powiedzieć, że Miedzianka, która zniknęła, przeobraziła się w miejsce nie tylko opuszczone, ale przede wszystkim puste. Takie też w zestawieniu z dawną fotografią zobaczył Filip Springer. A ponieważ, jak zauważa Ewa Wiegant, miejsce puste domaga się wypetnienia, którym może być literatura, opowieść, narracja ${ }^{34}$, ze spotkania reportażysty z pustką po urokliwym miasteczku zrodziła się książka. Ta wykonana przez reportera praca pisarska jest jednocześnie działaniem niejako na przekór naturalnemu biegowi rzeczy, reprezentowanemu przez wskazaną wyżej przyrodę, która „zajęła” miejsce po Miedziance, zakrywając ślady tragicznej historii ${ }^{35}$. Warto dodać, że literatura, wypełniając, zastępując to, co zostało zniszczone, „wymazane”, przywraca pamięć, nie pozwala zapomnieć, ale też ożywia to miejsce i niejako je kreuje ${ }^{36}$. W takim sensie staje się ona rezerwuarem pamięci. Szczególnie istotnymi są tutaj miejsca

29 Pisze o tym także Springer: Gdy do poniemieckiego domu wprowadzata się jakaś polska rodzina, to on [Tennenbaum - B.W.] przychodzit z gminną komisją i wyceniat poszczególne przedmioty. [...] Ale ludzie pieniędzy nie mieli, więc kazali [...] wyceniać tylko najpotrzebniejsze przedmioty [...], a cata resztę tego, co w domach byto, wystawiali na podwórka. [...] Jak przyszta zima, to ludzie tym drewnem palili w piecach. F. Springer, Miedzianka..., s. 90.

30 Więcej o historii miasteczka po 1945 r. zob. M. Makuch, T. Stolarczyk, Miedzianka. 700 lat..., s. 8298. Także jedna z rozmówczyń Springera wskazuje, że Miedzianka jest dziś na Zabobrzu. F. Springer, Miedzianka..., s. 250.

31 Pełny tekst uchwały z 1972 r. przedrukowano w cytowanej już książce M. Makucha i T. Stolarczyka, Miedzianka. 700 lat..., na s. 89-91.

32 Teren dawnego miasta miał po wyburzeniu zostać poddany rekultywacji i zalesieniu, prace zakończyły się jednakże na tym pierwszym etapie. Zob. tamże, s. 88-89.

33 R. Witczak Smutna historia dolnoślaskiego miasteczka..., s. 32.

34 Zob. E. Wiegant, Prozatorskie cykle przestrzenne: „Ludzie stamtad” Marii Dabrowskiej, „Nowele wtoskie” Jarostawa Iwaszkiewicza, „Opowieści galicyjskie” Andrzeja Stasiuka, [w:] tejże, Niepokoje literatury. Studia o prozie polskiej XX wieku, Poznań 2010, s. 349. Na to „uliteraturyzowanie” zwraca także uwagę Kamila Czaja, zob. K. Czaja, Rzecznik miejsc pokonanych: przestrzenie Filipa Springera, [w:] Strychy/ piwnice. Inne przestrzenie, red. A. Świeściak, S. Trela, Katowice 2015, s. 203-220.

35 Por. A. Szczepan, Krajobrazy postpamięci, „Teksty Drugie” 2014, nr 1, s. 111.

36 Podobne podejście do relacji między literaturą i miejscem odnaleźć można w geopoetyce, o czym pisała m.in. Elżbieta Rybicka zaznaczając, że miejsce (puste) wzywa do działania, staje się punktem wyjścia dla pisarskiego gestu, który na mocy kreacji przywraca w pamięci i świadomości świat na pozór utracony, zob. E. Rybicka, Geopoetyka. Przestrzeń i miejsce we wspótczesnych teoriach i praktykach literackich, Kraków 2014, s. 313. 
„wydrążone” z pamięci, które już fizycznie nie istnieją (lub ich funkcja uległa zmianie). Miejsca te pełnią funkcję mnemotechniczną (przypominają o swoim istnieniu poprzez dawną nazwę czy - jak to jest w przypadku Miedzianki - pusty plac). Takim metaforycznym, mnemotechnicznym miejscem w reportażu Springera jest nieistniejący cmentarz, na którym stanął obelisk poświęcony pamięci mieszkańców ${ }^{37}$, a ogólniej - większa część miasteczka, które tworzą obecnie ledwie widoczne zarysy domów porośnięte trawą. Ta przestrzeń unaocznia prawdę minionego czasu, stając się jednocześnie przestrzenią wyobrażoną, architektura literacka ${ }^{38}$. Miasteczko z reportażu Filipa Springera zatraciło swoje „real”, zastępowane tu i ówdzie przez dawne pocztówki, fotografie czy opisy umieszczone przy dawnych zabudowaniach w ramach powstałej w $2014 \mathrm{r}$. ścieżki historyczno-edukacyjnej Miedzianka-Mniszków-Gniewczyce ${ }^{39}$. Te elementy, oprócz wspomnień przekazanych przez wcześniejszych mieszkańców, tych, którzy doświadczyli traumy przesiedlenia i/lub zniknięcia Miedzianki, są istotnym tworzywem i uzupełnieniem dla budowania postpamięciowej narracji. Jednocześnie sprawiają, że Miedzianka staje się „krajobrazem pamięci”, odtwarzanym przez autora na podstawie rozmów z dawnymi mieszkańcami, przeczytanych źródeł, opracowań, fotografii i pocztówek. Krajobrazy pamięci - jak zauważa Sławomir Kapralski - sq zarazem domenami zapomnienia - uobecniaja nam jakąs przesztość, jednocześnie wymazuja ślady innych ${ }^{40}$. Tę prawidłowość można odnaleźć w przywoływanych w reportażu opowieściach czy (nieopublikowanej) kronice Dory Puschmann.

Miedzianka - odkryta i przypomniana przez Springera oraz „opowiadana” w kolejnych pojawiających się narracjach - przemienia się jednocześnie w swoiste miejsce pamięci (termin Pierre'a Nory). Jego metaforycznym znakiem są dwa napisy: jeden ze wspomnianego obelisku ustawionego na cmentarzu, na którym wyryto słowa: RUHET IN FRIEDEN/IHR SEID UNVERGESSEN / SPOCZYWAJCIE W POKOJU/ JESTEŚCIE NIEZAPOMNIANI ${ }^{41}$, oraz drugi - umieszczony na niewielkiej tabliczce przymocowanej do pnia starej śliwy rosnącej nieopodal dawnych zabudowań miasta: ERINNER DIE LEUTE VON KUPFERBERG (czyli Pamięci ludzi z Kupferbergu) ${ }^{42}$. W założeniu napis na kamieniu miał upamiętniać pierwotnych obywateli miasteczka przez swą dwujęzyczność stał się jednak łącznikiem pamięci o wszystkich mieszkańcach Kupferbergu/Miedzianki. I choć obydwa znaki nie mówią wprost o tragedii, ta myśl

Zob. F. Springer, Miedzianka..., s. 243.

38 Jak zauważa Rybicka, miasta prezentowane we współczesnej literaturze mają dwoistą postać: są tworem wyobraźni, jak i świadectwem doświadczenia kulturowego: miasta sq real and imagined, zob. E. Rybicka, Geopoetyka (o mieście, przestrzeni i miejscu we wspótczesnych teoriach i praktykach kulturowych), [w:] Kulturowa teoria literatury. Gtówne pojęcia i problemy, red. R. Nycz, Kraków 2006, s. 486.

39 Zob. Projekty. Ścieżka edukacyjna historyczno-geologiczno-przyrodnicza Miedzianka-Mniszków, [online] https://faktor.org.pl/index.php/projekty/22-sciezka-edukacyjna-historyczno-geologiczno-przyr odnicza-miedzianka-mniszkow.html, 30 VII 2020.

40 S. Kapralski, Pamięć, przestrzeń, tożsamość. Próba refleksji teoretycznej, [w:] Pamięć, przestrzeń, tożsamość, red. tenże, Warszawa 2010, s. 27.

$41 \quad$ F. Springer, Miedzianka..., s. 243.

42 Tamże, s. 257. 
nasuwa się sama, gdy człowiek rozejrzy się po nieistniejącym cmentarzu, na którym stanął obelisk, czy w miejscu, gdzie rośnie osamotniona zdziczała śliwa. W ten sposób Miedzianka, „odkryta” przypadkowo przez Filipa Springera i przeniesiona dzięki jego „archeologicznej” pracy do literatury, połączyła w sobie wspomniane oblicza: miejsca pustego (niczyjego, opuszczonego i zapomnianego na kilka dekad) i miejsca pamięci. Chociaż tym ostatnim staje się wciąż - dzięki kolejnym narracjom i praktykom postpamięci, które symbolicznie i metaforycznie „zapełniają” pustkę i przełamują ciszę, będącą znakiem rozpoznawczym współczesnej Miedzianki.

Warto nadmienić, że budując swą opowieść, Springer sięgnął z jednej strony po atrakcyjną! - formułę sensacyjną, rozpoczynając swą opowieść od obrazowego przedstawienia znikania miasteczka, $\mathrm{z}$ drugiej jednak pokazał niemożność odkrycia prawdy o Miedziance i jej zniknięciu. Pisarz sam porównał swoją pracę do pracy archeologa, który nie poprzez bezpośrednie doświadczenie, ale za pomocą odnajdywanych artefaktów, przedmiotów, śladów, jak i głosów czy dokumentów próbuje odtworzyć historię. Jak pisze, pewnie gdybym pochodzit po świeżo zaoranych polach, znalaztbym kilka fragmentów pottuczonych talerzy. Ale i one nic by nie znaczyty - cata ta archeologia jest zbędna, bo potem i tak jest wymyślanie, siedzenie w autobusie z Jeleniej Góry, gapienie się przez okno i zastanawianie $e^{43}$. Autor wskazuje tym samym, że ma świadomość, iż nie da się spisać ani odtworzyć jednej spójnej historii (znikania) Miedzianki. Postpamięciowe empatyczne odtwarzanie - by nawiązać do słów Hirsch - u niego wiąże się z przyjętą świadomie rolą rekonstruktora zdarzeń, które to zdarzenia nie zrodziły się w jego wyobraźni, ale są wynikiem ustrukturyzowania rzeczywistości, balansowania pomiędzy czerpaniem ze źródeł i ich przeżywaniem, literackim przetwarzaniem.

\section{OCALAJĄCA MOC SZTUKI: MIEDZIANKA JAKO INSPIRACJA}

Ciszą i pustką po Miedziance przywołanej w reportażu Filipa Springera zainspirowali się autorzy ${ }^{44}$ drugiej wspomnianej publikacji, a wcześniej również wystawy zatytułowanej - Miasto, którego nie byto/, Die Stadt, die nicht gewesen ist. Także tutaj uwidaczniają się cechy postpamięciowych praktyk wskazane przez Hirsch: empatia, kreacja i - może najwyraźniej - wyobraźnia. Oprócz inspiracji reporterską książką Springera za podstawę owego działania można uznać przekonanie, że sztuka, choć - co oczywiste - nie odwróci procesu znikania, to może być jednym ze sposobów, drogą czy też pomocą $w$ procesie aktywnego leczenia traumy tego miejsca ${ }^{45}$. Jak bowiem zauważył współautor projektu Marek Wasilewski, sztuka coraz czésciej [...] dotyka problemów zwiazanych z odczytywaniem historii, jej reinterpretacji, odkrywania wypartych watków i niechcianych obrazów.

\footnotetext{
F. Springer, Miedzianka..., s. 123.
}

${ }_{44}$ Tę inspirację wyrażają wprost uczestnicy projektu, np. Ola Kubiak pisze, że dziś dawne miasteczko, a później wieś - Kupferberg i Miedzianka - to zaledwie kilka zamieszkatych domów i ksiązka Filipa Springera, która przywotata do życia dawne legendy $i$ wzmogta zainteresowanie „miejscem, którego nie ma”, zob. O. Kubiak, RADON MACHINE, [w:] Miasto, którego nie byto..., s. 95.

45 M. Wasilewski, W poszukiwaniu pamięci miejsca, [w:] Miasto, którego nie byto..., s. 12. 
[...] ukazuje to, co niewypowiedziane i niewypowiadalne $e^{46}$. Artysta dodaje, że Miedzianka to miejsce, które posiada swoją pamięć, ta pamięć jest tym bardziej przejmująca, ponieważ jest pamięcia traumatycznq i wyparta i ten właśnie aspekt znalazł się także u podstaw artystycznych realizacji uczestników projektu. Jak wskazuje Janina Hobgarska - współredaktorka publikacji i kuratorka poprzedzającej ją wystawy - ideą, która przyświecała uczestnikom dotkniętym, poruszonym zniknięciem miasta i losami jego mieszkańców, była konfrontacja $z$ dziejami tego miejsca, [...] poprzez sztuke, poprzez wypowiedź artystyczna. Chodzito nam o to, aby dotknać Miedzianki w takim wymiarze, który, będąc niezwykle ulotny, umyka przeciętnemu obserwatorowi. Aby dojrzeć zawieszony gdzieś pośród pozostatości miasta zapis - tajemniczy, nostalgiczny, ale i tragiczny ${ }^{47} \mathrm{i}$ dalej, aby ukazać zdarzenia, które przenikaja sie z fikcją i osobista interpretacją, bo artystyczna fikcja jest przecież $w$ sztuce ze wszelkich stron pożądana, jest równoprawnym narzędziem przedstawienia rzeczywistości $i^{48}$. Artystyczne realizacje poprzedziła wędrówka po Miedziance - zarówno na kartach reportażu Springera, jak i wśród jej pozostałości. Jak dodaje Wasilewski, chodzimy po Miedziance na kartach ksiażki Filipa Springera. Przemierzamy nieznane nam przestrzenie, oczami wyobraźni widzimy miasto, którego nie byto, bo każdy przywotywany przez nas obraz [...] jest obrazem $z$ wyobraźni ${ }^{49}$.

W tych ostatnich słowach ujawnia się zatem kolejne oblicze Miedzianki - jako miejsca wyobrażonego i inspirującego. Pojawia się tutaj także motywacja do podjęcia artystycznych działań, których pokłosiem jest omawiana publikacja. Tą motywacją i inspiracją była książka Filipa Springera. Zanim jednak przejdę do ukazania, jak ta druga narracja ma się do swojego „źródła”, warto wskazać, że owo przemierzanie Miedzianki (i tej literackiej i tej rzeczywistej - choć zarazem widmowej), wiąże się z istotą działania postpamięci. Z jednej strony uwypuklony został tutaj przestrzenny aspekt postpamięci, z drugiej świadomość, że kreacyjny aspekt postpamięci domaga się ruchu, aktywnego zaznaczenia własnej obecności w zastanej przestrzeni „tu i teraz”. Fizyczny kontakt z twardą materią, którą w tym przypadku jest „miejsce po (mieście)”, wiąże się z wpisaniem w nią własnej pamięci, a dzięki uruchomieniu empatii i uważności tworzą one postpamięciowe praktyki, pozwalające wydobyć przeszłość, niejako „zobaczyć” obrazy $\mathrm{i}$ „usłyszeć" głosy tego miejsca. Na ten aspekt w projekcie Miasto, którego nie byto zwraca uwage Joanna Mielech, pisząc, że wystawa o Miedziance przywotuje, ale nie wspomnienia, bo te dotycza miejsc znanych; może raczej wywotuje duchy przysztości ${ }^{50}$. Jednocześnie, być może ze względu na fakt, że tak niewiele materialnych śladów Miedzianki da się dziś odnaleźć, szczególnie ten drugi, dźwiękowy aspekt znalazł odzwierciedlenie

\footnotetext{
Tamże, s. 11.

A. Gierak, Miasto, którego nie byto, „Nowiny Jeleniogórskie” 2013, 28 IX, [online] https://www.nj24. $\mathrm{pl} /$ article/miasto-ktorego-nie-bylo, 23 XI 2020.

49 M. Wasilewski, Wposzukiwaniu pamięci miejsca..., s. 11.

50 J. Mielech, Seans mediumiczny Miedzianki, „Czas Kultury” 2013, 24 X, [online] http://czaskultury. pl/czytanki/miasto-ktorego-nie-bylo-miedzianka/, 21 XI 2020.
}

48 Tamże. 
w omawianych artystycznych realizacjach. Echo dawnego, ślad rytmu wnętrza Miedzianej Góry. Dużo na tej wystawie szumów, odgtosów, strzępów, nastuchów ${ }^{51}$.

Zestawiając ten projekt, a szczególnie jego zapis w postaci publikacji z Miedzianka. Historia znikania można powiedzieć, że o ile zainteresowanie historią Miedzianki w przypadku Springera zaczęło się przypadkowo, o tyle tutaj mamy do czynienia ze świadomym działaniem, przemyślanym i zaplanowanym. Podobnie jak autor Miedzianki, również artyści materializujący swoje doznawanie historii Miedzianki przekazują je, opierając się głównie na opowieściach, domysłach, zdobywanych informacjach. Są na wystawie nagrania wspomnień, ludzkie głosy, urywki dźwięków z miejsca tętniącego niegdyś życiem. W odniesieniu do formy w pierwszym przypadku jest to reportaż - w drugim można mówić o „dokumencie życia społecznego”. Obydwie narracje wyrastają z inspiracji przestrzenią, u Springera chodziło o jednak docieranie do świadków jej istnienia i znikania, artystyczny projekt z kolei opiera się na relacji (i narracji) już istniejącej, przestrzeń miasteczka staje się „tworzywem” i przestrzenią do podjęcia artystycznych działań. Obydwie narracje składają się z „głosów” - u Springera przywołanie wspomnień dawnych mieszkańców i ich potomków ma być elementem tworzonej przez niego opowieści o Miedziance. W przypadku Miasta, którego nie byto właściwie każdy z pojawiających się tutaj głosów: esejów, opisów, komentarzy do projektów może stanowić odrębną historię o Miedziance, czy też wokół niej. Springer utkał swą narrację, opierając się na wspomnieniach, widokach z pocztówek czy przedmiotach. W drugiej publikacji (jak i projekcie) te elementy, można powiedzieć, są dopiero kreowane - „rzeczy” - w sensie dzieł sztuki takich jak instalacje czy wiersze - powstają. A zatem nie tyle służą (albo raczej nie wszystkie) przypomnieniu historii zapomnianego miasteczka, ile zbudowaniu na fragmentach, resztkach, pozostałościach czegoś nowego. Zarazem jednak są przejawem ujawnienia się głosów przeszłości w teraźniejszości. W obydwu narracjach ważną rolę odgrywają fotografie stanowiące u Springera przede wszystkim uzupełnienie treści czy ślad pamięci, a w omawianym projekcie dowód upamiętnienia w sztuce, świadectwo inspiracji. Obydwie postpamięciowe praktyki różni zatem forma, ale łączy istotny element wskazany przez Hirsch jako podstawowy zabieg postpamięci - kreacja: u Springera uwidaczniająca się w pisarskiej formie reportażu literackiego; w Mieście, którego nie byto w dziełach sztuki. Pojęciem, które powtarza się w tej drugiej książce wielokrotnie, jest „wyobraźnia” (po raz kolejny zatem przywołujemy kategorię Hirsch), Miedzianka jest miastem z wyobraźni i do wyobraźni przemawiającym. Jej zniknięcie jest punktem wyjścia - i to element wspólny obydwu narracji: w pierwszej do opowiedzenia, przypomnienia jej historii, w drugiej - do stworzenia dzieła sztuki. W obydwu przypadkach jest jednym ze sposobów odpominania historii tego miejsca, próbą konfrontacji z jego tragiczną historią i poprzez subiektywne, indywidualne działanie - „uobecnieniem nieobecności” tak istotnym w przypadku pracy postpamięci. Można zatem stwierdzić, że zarówno pisarstwo Springera, jak i twórcze działania artystów mają podobny cel: przywrócić pamięć i - poniekąd - umożliwić

51 Miasto, którego nie byto, „Szum” 2013, 15 XI, [online] https://magazynszum.pl/miasto-ktorego-niebylo-projekt-i-wystawa-o-miedziance/, 21 XI 2020. Szczegółowy opis „dźwiękowych” realizacji i wrażeń znaleźć można we wspomnianym wyżej artykule J. Mielech, Seans mediumiczny Miedzianki... 
(po)radzenie sobie z traumą, trudną historią. To z kolei są istotne elementy odpominania - które nie jest możliwe bez uświadomienia sobie poczucia straty, niepamięci, zapomnienia i leżących u ich podstaw traumatycznych przeżyć (tu przede wszystkim związanych z polską tragedią miejsca - jego zniknięciem). Sztuka, podobnie jak literatura, pozwala na nowo przeżyć strach, minione emocje, skoro nie można tego zrobić w rzeczywistości (która nie istnieje - bo de facto nie ma miejsca i nie ma jego mieszkańców). Jednocześnie, jak zauważa Wasilewski,pamięć miejsca wiąże się z poczuciem osobistej odpowiedzialności, ze swoistym poczuciem dziedziczenia miejsc z catym obciażeniem tego, co się w nich wydarzyto ${ }^{52}$. Te słowa mogą byśs swoistym mottem i wykładnią obydwu postpamięciowych praktyk: Springer tę „sprawiedliwość” stara się oddać w reportażu, artyści, tworząc właśnie w tym miejscu czy też z inspiracji tym miejscem swoje dzieła. Te słowa wskazują także, że (autobiograficzne) miejsce dotknięte Filipa Springera stało się miejscem wspólnym, takim, za które zechcieli wziąć odpowiedzialność następni. Uruchomione zostały pokłady postpamięci i działania prowadzące w stronę odpominania, któremu towarzyszy również przemiana oblicza miejsca: z miasta przeznaczonego do życia, przez miejsce puste w miejsce pamięci.

Rekonstrukcja pamięci przy pomocy sztuki może mieć różne powody i różnie może się ujawniać. Każdy na swój sposób może, podążając za usłyszanym/zapamiętanym słowem, miejscem, przedmiotem, odpominać historię Miedzianki, przywracać pamięć o niej, (prze)żyć żałobę, by na tej świadomości budować niejako na nowo pamięć tego miejsca, z zachowaniem wspomnień i wiedzy o jego wcześniejszym istnieniu, trudnej historii i mieszkańcach. To stwierdzenie koresponduje ze słowami Filipa Springera, według którego Miedzianka zniknęta, a to jej zniknięcie opisuje dziś wyjątkowość tego miejsca. [...] Miedzianka daje możliwość wstuchania się w pustkępo mieście, poczucia melancholii, która sprzyja skupieniu na sprawach ważnych ${ }^{53}$. Tak też zrobili uczestnicy projektu i zarazem autorzy wystawy w jeleniogórskim BWA, którzy zainspirowani reportażem o Miedziance, na swój własny artystyczny sposób (z)mierzyli się z jej przestrzenią, historią, traumą.

Narracja w stworzonej przez nich publikacji akcentuje przede wszystkim rolę Miedzianki jako miejsca inspirującego, nakazującego zadawać pytania o relacje między miejscem i pamięcią. Wskazuje przy tym, że sztuka (a w tym literatura) może tę pamięć ocalać, ale także że nie ma jednej pamięci o tym miejscu ${ }^{54}$ : przez swoją tragiczną historię Miedzianka jest dziś bowiem głównie „miejscem w wyobraźni”, odmiennym dla każdego, kto będzie chciał ją zobaczyć, poznać, przemierzyć. Karolina Janikowska - jedna z uczestniczek projektu - wskazuje: Kazddy, kto przystuchuje się historii Miedzianki, stapa po miejscach dawnych kamienic, [...] widzi ja inaczej. Próbuje przywotać jej obraz, którego nigdy wcześniej nie zobaczyt. Projektuje to miejsce. [...] Powstaje więc tyle Miedzianek, ile

52 Tami̇e, s. 13.

53 F. Springer, Miedzianka Fest. Coraz większy sukces. Coraz mniej ciszy, „Gazeta Wyborcza” 2019, 9 IX, [online] https://wyborcza.pl/duzyformat/7,127290,25166244,miedziankafest-coraz-wiekszy-sukcescoraz-mniej-ciszy.html, 30 VIII 2020.

54 Jak pisał Pierre Nora, Historia byta jedna. Pamięci byto wiele. Epoka upamiętniania. Rozmowa z Pierrem Nora, [w:] J. Żakowski, Rewanż pamięci, Warszawa 2002, s. 64. 
odwiedzajacych ją przechodniów 55 . Aurelia Nowak dodaje, iż całkowite niemalże zniknięcie dawnego miasteczka na pograniczu polsko-niemieckim niepokoi każdego, kto przeczyta lub ustyszy od mieszkańców o jej losach [...]. Nic jednak nie sprawi, że dowiemy się, jakim miejscem byta w rzeczywistości. Dziś dla każdego jest czym innym, a jej pustka prowokuje do kreacji. [...] Miedzianka jednak nie zniknie, dopóki pamięć o niej nie ulegnie zatarciü ${ }^{56}$. W tych słowach po raz kolejny wybrzmiewa wskazana przez Marianne Hirsch kategoria wyobraźni i kreacyjności, stanowiąca istotny element (praktyki) postpamięci, ale też ujawnia się swoiste dziedzictwo tego miejsca - niepokój, poczucie pustki ${ }^{57}$.

W Miedziance w szczególny sposób uwidacznia się upływ czasu - Springer w swojej opowieści pokazuje, jak w rozmaitych wymiarach w przestrzeni dokonuje się przemijanie. Na ten aspekt w swojej inspiracji Miedzianką zwrócili uwagę także uczestnicy omawianego projektu. Jak wskazuje Maria Dmitruk: W linii horyzontalnej wędrują przesiedlane $z$ wyroku historii rodziny różnych narodowości, wertykalnie zapadaja się poktady drażonej przez stulecia ziemi $i^{58}$. Artystka odnosi się zatem do drugiej, a właściwie pierwszej wspomnianej wcześniej traumy tego miejsca - którą były przesiedlenia. Jak dodaje Miłosz Kamiński, to, co przeminęło, staje się przeszłością, która nie istnieje obiektywnie, a jest relacją i jako taka pozostaje w stużbie teraźniejszości, polityki historycznej czy sposobów myślenia o świecie $e^{59}$. Tym, co pozostało, są opowieści i ślady, rzeczy tak bardzo niepewne i zarazem przecież niezbite dowody, że tylko wspomnienia porzadkują ten świat po dwakroć miniony, wyrwany niemieckim mieszkańcom w następstwie powojennego wytyczania granic i zarazem odebrany ich następcom, często również wygnańcom ${ }^{60}$. Zaznaczona tutaj rola opowieści jako jednej z praktyk postpamięci wskazuje na jeszcze jeden cel owych działań, które zarówno w przypadku omawianej publikacji, jak i Miedzianki Springera powadzą w stronę ukazania wspólnoty losu niemieckich i polskich mieszkańców Kupferbergu/Miedzianki. Poszukiwanie odpowiedzi na pytanie o to, jak doszło do zniknięcia miasteczka, mogłoby wiązać się z próbą „namierzenia” winnych, tymczasem, jak zauważyła Kamila Gieba, Springer dąży do upamiętnienia miejsca w sposób holistyczny. Nie pomija historii żadnej narodowości, [...] nie nadaje nikomu wytacznego prawa do terytorium ${ }^{61}$. Miłosz Kamiński, wskazuje, że to ujęcie i zrozumienie sprawia, że przesztość zaczyna żyć.

55 K. Janikowska, IN KUPFERBERG, [w:] Miasto, którego nie byto..., s. 114, 117.

56 A. Nowak, Miasto, którego nie byto, [w:] Miasto, którego nie byto..., s. 76.

57 W tym miejscu tylko nadmienię, że nie chodzi wyłącznie o pustkę rozumianą jako brak, ale w heideggerowskim znaczeniu jako miejsce będące „wydobywaniem na jaw”, domagające się urzeczywistnienia tkwiącego w nim potencjału, miejsce znaczące. Więcej zob. M. Heidegger, Sztuka i przestrzeń, przeł. C. Woźniak, „Principia III” 1991, s. 127-128.

58 M. Dmitruk, UBI SUNT, [w:] Miasto, którego nie byto..., s. 98.

59 M. Kamiński, Miedzianka: przesztość jako teraźniejszość, [w:] Miasto, którego nie byto..., s. 60.

60 Tamże, s. 63.

61 K. Gieba, Memento dla prowincji..., s. 562.

62 M. Kamiński, Miedzianka: przesztość jako teraźniejszość..., s. 63. 


\section{PODSUMOWANIE}

Podsumowując refleksje wokół postpamięciowych narracji o Miedziance, można stwierdzić, że wraz z nimi widzimy, jak konstruowana i rekonstruowana może być pamięć i niepamięć, widzimy też wędrowanie od znikania do odpominania, od niepamięci do pamiętania, od miejsca życia do miejsca pamięci.

Mówimy tak wiele o pamięci, ponieważ tak mato $z$ niej zostato - wskazywał Pierre Nora $^{63}$. Można dodać, że działamy tak wiele dla pamięci, ponieważ tak mało z niej zostało, co, jak się zdaje, „pasuje” do narracji o Miedziance. Należy przy tym zaznaczyć, że tymi, którzy przede wszystkim udzielili swojego głosu w książce Filipa Springera, byli żyjący jeszcze niemieccy mieszkańcy Kupferbergu, jak i późniejsi polscy z Miedzianki. Ci pierwsi pozostawili po sobie ślady - w postaci obelisku czy tabliczki na drzewie upamiętniającej autochtonów. Na polską (post)pamięć czy też upamiętnienie Miedzianki trzeba było poczekać. I stało się to za sprawą przedstawiciela kolejnej generacji, który nie doświadczył bezpośrednio traumy przesiedlenia czy też niszczenia/ znikania miasteczka - Filipa Springera. Miedzianka stała się dla niego miejscem autobiograficznym - raz wspomniana, nie pozwoliła o sobie zapomnieć i stała się inspiracją do napisania książki. Ta z kolei uruchomiła kolejne osoby i działania - od tabliczek informacyjnych umieszczonych w przestrzeni po mieście poprzez spektakl teatralny, który z desek teatru w Jeleniej Górze przeniósł się do Miedzianki, po wystawę prac i publikację Miasto, którego nie byto, a wreszcie komiks oraz mural poświęcony miasteczku, który umieszczono na jednym z bloków na jeleniogórskim Zabobrzu. Puste miasteczko ożyło w jeszcze innym wymiarze - jego przestrzeń od kilku lat w letnie dni zamienia się w miejsce spotkań wielbicieli literatury - w ramach Miedzianka Fest. To, co pozostało: kościól, wybudowany nieopodal browar, ale przede wszystkie zarosłe trawą miejsce po mieście, stało się (na powrót) agorą do spotkań i snucia opowieści. To pokazuje przemianę oblicza Miedzianki: z miejsca do życia i pracy, a później miejsca zapomnianego, w miejsce pamięci, które na różne sposoby, poprzez rozmaite działania przypomina historię miasteczka, także tę trudną.

Miasteczka nie da się ożywić, można jedynie o nim pamiętać. Pamiętanie to, wobec braku kolejnych pokoleń ludzi z Miedzianki, może być kontynuowane przede wszystkim za sprawą literatury i sztuki, w których mocno uwidaczniają się postulowane przez Marianne Hirsch „kreacja i wyobraźnia”. Można i trzeba „opowiadać”, wciąż na nowo i na różne sposoby, językiem literatury, sztuki, teatru itd. Narracje są sposobem ponownego przeżywania. Dopóki owa historia, trauma, zagłada (miasta) nie daje spokoju, porusza, konieczne jest jej przepracowywanie, a że nie ma powrotu do przeszłości, nie da się ani odwrócić, ani zamknąć owej historii, bo - chociażby - fizyczne ślady: pustka, cisza, nierówności, fragmenty zabudowań i „dziwnie”, jakby „nigdzie” usytuowany kościół przypominają o niej, dopóty konieczne są „praktyki postpamięci”. Praca pamięci i praca (wy)twórcza potrzebują ruchu, działania, które jest rodzajem piętna odciśniętego w zastanej przestrzeni. W interesujących mnie praktykach postpamięciowych

63 P. Nora, Między pamięcia a historia: Les Lieux de Mémoire, „Tytuł roboczy: Archiwum” 2009, nr 2, s. 4. 
szczególną rolę odgrywa przestrzeń. To bowiem traumatyczne doświadczenie związane z jej zniknięciem, niepokojącą i pozorną (bo uwidaczniają się w niej ślady po mieście) pustką legło u podstaw podjętych działań - literackich i artystycznych. Wzmocniła je dodatkowo cisza - będąca znakiem rozpoznawczym dzisiejszej Miedzianki, ale też znakiem niepamięci, zapomnienia, a zatem ciszy znaczącej, która de facto domaga się przypomnienia i przywrócenia głosu i pamięci o tych, którzy byli tutaj wcześniej i których historia skończyła się wraz z zagładą miasta. Aby jednak tego dokonać, trzeba wejść w tę przestrzeń, nawiązać z nią relację, a zatem poświęcić jej swoją wrażliwość, uważność, empatię, czas i... wyobraźnię. To dopiero pozwala na „przywołanie” niejako ducha (czy też duchów) z przeszłości i odpomnienie tragicznej i traumatycznej historii tego miejsca. Dzięki tej sprawczości, odgrywaniu wspomnień i przekuwaniu ich w opowieść, akt sztuki itp. dokonuje się niejako urzeczywistnienie tej przestrzeni. Przepracowywanie trudnej przeszłości i pamięci nie jest procesem łatwym, stąd też domaga się wciąż i na różne sposoby dopowiadania, kreowania, przypominania, by dzięki tym zabiegom móc zarówno poczuć się pełnoprawnym depozytariuszem dziedzictwa danego miejsca, oddać sprawiedliwość wszystkim dawnym budowniczym i mieszkańcom miasta, jak i w oparciu o nie budować tożsamość - swoją i miejsca, której istotnym elementem jest wspólnota pamięci. Przywołane tutaj narracje tworzą swoisty wielogłos przypominający tragiczną historię Miedzianki i próbujący z postpamięciowej perspektywy „uporać” się z jej zniknięciem - żeby na nowo uruchomić pamięć o niej, nadać nowe znaczenia, a wreszcie - jak zauważył Jarosław Szczyżowski - aby przekazać pewne wartości w tym [...] świecie, [...] zachować pamięć miejsc dla potomnych, a przede wszystkim, żeby nie pozostawić po sobie wstydu. [...] bo jesteśmy w tej przestrzeni tylko na chwi$l_{\ell}^{64}$. Praktyki te przyczyniają się - w szerszej perspektywie - do powolnego wyzwalania się z odziedziczonej traumy, pozwalają na odkrywanie prawdy i budowanie w oparciu o nią niemiecko-polskiej wspólnoty (pamięci).

\section{BIBLIOGRAFIA}

Czaja K., Rzecznik miejsc pokonanych: przestrzenie Filipa Springera, [w:] Strychy/piwnice. Inne przestrzenie, red. A. Świeściak, S. Trela, Katowice 2015.

Czermińska M., Miejsca autobiograficzne. Propozycja w ramach geopoetyki, „Teksty Drugie” 2011, nr 5.

Darska B., Pamięć codzienności, codzienność pamiętania. Szkice o reportażu polskim XXI wieku, Gdańsk 2014.

Epoka upamiętniania. Rozmowa z Pierrem Nora, [w:] J. Żakowski, Rewanż pamięci, Warszawa 2002.

Gieba K., Memento dla prowincji. O Miedziance. Historii zanikania Filipa Springera, [w:] Pogranicza, Kresy, Wschód a Idee Europy. Seria II: Wiktor Choriew in memoriam, red. A. Janicka, G. Kowalski, Ł. Zabielski, Białystok 2013.

64 J. Szczyżowski, Miedzianka. Przewodnik po mieście, którego nie ma, Jelenia Góra-Miedzianka 2017, s. 59. 
Gierak A., Miasto, którego nie byto, „Nowiny Jeleniogórskie” 2018, 28 IX, [online] https:// www.nj24.pl/article/miasto-ktorego-nie-bylo.

Heidegger M., Sztuka i przestrzeń, przeł. C. Woźniak, „Principia III” 1991.

Hirsch M., Family Frames. Photography, Narrative and Postmemory, Cambridge 1997.

Hirsch M., Żatoba i postpamięć, przeł. K. Bojarska, [w:] Teoria wiedzy o przesztości na tle wspótczesnej humanistyki. Antologia, red. E. Domańska, Poznań 2010.

Kaniowska K., „Memoria” i „postpamięç" a antropologiczne badanie wspólnoty, [w:] Codzienne $i$ niecodzienne. O wspólnotowości w realiach dzisiejszej Łodzi, red. G.E. Karpińska, Łódź 2004.

Kapralski S., Pamięć, przestrzeń, tożsamość. Próba refleksji teoretycznej, [w:] Pamięć, przestrzeń, tożsamość, red. S. Kapralski, Warszawa 2010.

Karkonoska Nagroda Literacka 2019 wręczona!, [online] http://www.kpswjg.pl/pl/news/ karkonoska-nagroda-literacka-2019-wreczona.

Kazimierowska K., Rozmowa z Filipem Springerem o książe Miedzianka, „Rzeczpospolita” 2011, 10 XI, [online] https://www.rp.pl/artykul/750083-Rozmowa-z-Filipem-Springerem-oksiazce-Miedzianka.html.

Kolarzowa R., Zwidy, majaki, powidoki czyli meandry postpamięci. Między Dominkiem LaCapra a Giorgio Agambenem, „Kwartalnik Filozoficzny” 2015, vol. 43, z. 3.

Lewicka M., Psychologia miejsca, Warszawa 2012.

Makuch M., Stolarczyk T., Miedzianka. 700 lat dziejów górniczego miasta, Legnica 2013.

Miasto, którego nie byto, „Szum” 2013, 15 XI, [online] https://magazynszum.pl/ miasto-ktorego-nie-bylo-projekt-i-wystawa-o-miedziance/.

Miasto, którego nie byto/ Die Stadt, die nicht gewesen ist, red. J. Hobgarska, A. Nowak, M. Wasilewski, przeł. K. Mądry, Z. Nierodziński, W. Wojciechowski, Jelenia Góra 2013.

Mielech J., Seans mediumiczny Miedzianki, „Czas Kultury” 2013, 24 X, [online] http://czaskultury.pl/czytanki/ miasto -ktorego-nie-bylo-miedzianka/.

Nora P., Między pamięcią a historią: Les Lieux de Mémoire, „Tytuł roboczy: Archiwum” 2009, nr 2.

Orłowski H., Warmia z oddali. Odpominania, Olsztyn 2000.

Projekty. Ścieżka edukacyjna historyczno-geologiczno-przyrodnicza Miedzianka - Mniszków, [online] https://faktor.org.pl/index.php/projekty/22-sciezka-edukacyjna-historyczno-geolog iczno-przyrodnicza-miedzianka-mniszkow.html.

Ricoeur P., Pamięć, historia, zapomnienie, przeł. J. Margański, Kraków 2012.

Rybicka E., Geopoetyka. Przestrzeń i miejsce we wspótczesnych teoriach i praktykach literackich, Kraków 2014.

Rybicka E., Geopoetyka (o mieście, przestrzeni i miejscu we wspótczesnych teoriach i praktykach kulturowych), [w:] Kulturowa teoria literatury. Gtówne pojęcia i problemy, red. R. Nycz, Kraków 2006.

Sierbińska A., Konstrukcje pamięci: „postpamięc”" Marianne Hirsch, postpamięć Christiana Boltanskiego, „Konteksty. Polska Sztuka Ludowa” 2010, nr 1.

Stownik geografii turystycznej Sudetów, t. 5 Rudawy Janowickie, red. M. Staffa, Wrocław 1998.

Sontag S., O fotografii, przeł. S. Magala, Kraków 2009.

Springer F., Miedzianka. Historia znikania, Wołowiec 2011. 
Springer F., Miedzianka Fest. Coraz większy sukces. Coraz mniej ciszy, „Gazeta Wyborcza” 2019, 9 IX, [online] https://wyborcza.pl/duzyformat/7, 127290,25166244,miedziankafestcoraz-wiekszy-sukces-coraz-mniej-ciszy.html.

Szczepan A., Krajobrazy postpamięci, „Teksty Drugie” 2014, nr 1.

Szczepan A., Polski dyskurs posttraumatyczny. Literatura polska ostatnich lat wobec Holocaustu i tożsamości żydowskiej, [w:] Kultura po przejściach, osoby z przesztością. Polski dyskurs postzależnościowy - konteksty i perspektywy badawcze, red. R. Nycz. Kraków 2011, s. 239-256.

Taborska K., Literatura miejsc niemiecko-polskich po roku 1989. Polonocentryczne strategie geografii wyobrażonej, [w:] Geografia wyobrażona regionu. Literackie figury przestrzeni, red. D. Kalinowski, M. Mikołajczak, A. Kuik-Kalinowska, Kraków 2014.

Szczyżowski J., Miedzianka. Przewodnik po mieście, którego nie ma, Jelenia Góra-Miedzianka 2017.

Szura L., Filip Springer, „Miedzianka. Historia znikania”, [online] https://culture.pl/pl/dzielo/ filip-springer-miedzianka-historia-znikania.

Wiegant E., Prozatorskie cykle przestrzenne: „Ludzie stamtą” Marii Dąbrowskiej, „Nowele wtoskie” Jarostawa Iwaszkiewicza, „Opowieści galicyjskie” Andrzeja Stasiuka, [w:] E. Wiegant, Niepokoje literatury. Studia o prozie polskiej XX wieku, Poznań 2010.

Żyrek-Horodyska E., Kartografowie codzienności. O przestrzeni (w) reportażu, Kraków 2019.

Żyrek-Horodyska E., Reportażowy dyskurs o postpamięci. Casus więzów krwi Jeana Hatzfelda, „Kultura-Media-Teologia” 2018, nr 32, https://doi.org/10.21697/kmt.32.3.

Barbara WEŻGOWIEC - absolwentka polonistyki i kulturoznawstwa UJ, doktor literaturoznawstwa. Asystent w Instytucie Studiów Międzykulturowych UJ i nauczyciel w I LO im. B. Nowodworskiego w Krakowie. Jej zainteresowania naukowe dotyczą zagadnienia regionalizmu w literaturze, kategorii przestrzeni w literaturze, relacji między pamięcią i literaturą oraz narracji tożsamościowych. Ostatnio opublikowała monografię Pisarz i miasto. Gdańsk w prozie Stefana Chwina (2019). 